\title{
Adoption of Mobile Money Services among University Students in Tanzania
}

\author{
Beatrice Ndekwa ${ }^{1}$, Alex Juma Ochumbo $(\mathrm{PhD})^{2}$, Alberto Gabriel Ndekwa $(\mathrm{PhD})^{3}$, \\ Kalugendo Elizeus John ${ }^{4}$
}

\author{
${ }^{1}$ BBA Students-Ruaha Catholic University \\ ${ }^{2,3}$ Lecturer, Ruaha Catholic University \\ ${ }^{4} \mathrm{PhD}$ Student-The Open University of Tanzania
}

\begin{abstract}
The focus of the study was to assess factors influencing adoption of mobile money services among university students in Tanzania. The study adopted a quantitative approach where questionnaire was used to collect data from students of Ruaha Catholic University. Stratified sampling was used to ensure sample representation among students from different faculty and level of education thereafter simple random sampling was used to pick a sample size of 383 of respondents from the strata developed.

Exploratory factors analysis was used to ensure construct validity of four construct. Cronbach alpha indicated that all variables had achieved an accepted range of internal consistent by yielding a Cronbach alpha p-value grater that 0.6.Using multiple regression analysis, findings revealed that students' attitude, social factor and facilitating condition are significant factors influencing university students adoption of mobile money services in Tanzania.Based on these findings this study concludes that students' attitudes, social pressure and facilitating conditions are factors influencing university students' adoption of mobile money services in Tanzania higher learning institutions. This study recommend that, for speeding up the adoption of mobile money services, services provider should attract more peer pressure that could help to increase mobile money adoption among university students.
\end{abstract}

Keywords-Mobile Money Services, University Students.

\section{INTRODUCTION}

Information and communication technologies (ICTs) have enmeshed the globe in digital networks, and none is as widespread as the mobile technology, a technology with more than five billion subscriptions globally (Kazi and Mannan, 2013). As it is indicated in Tanzania basic education ICT policy of 2007 that the Integrate of mobile ICT in education enhance access, equity, quality and relevance of basic education, while stimulating and improving teaching and lifelong learning (URT,2007). This has enabled mobile devices to provide financial information, communication and transactions to students such as checking account balances, transferring funds and accessing other banking products and services from anywhere, at any time (Aboelmaged and Gebba, 2013). As argued by Cudjoe, et al. (2015) that the convenience offered by mobile money to students has enabled students toreceive and pay cash regardless of time and location. On the other hand, Hamza and Shah (2014) argued that the proliferation of handheld devices coupled with the high-speed mobile network has paved way for people to constantly interact and make transactions. According to Govender and Sihlali (2014) who argued that mobile money services help to provide time independence.

Despite of its benefits mentioned above, fast advances in the wireless technology and the intensive penetration of cell phones which have motivated banks and telecommunication companies to spend large budget on building mobile banking systems, but the adoption rate of mobile banking by university students is still underused than expected (Yu,2012).In addition, Kabir (2013) has also indicated that internet and other technology based transaction is not safe, not practical and would lead to fraud. Given this situation, this study intended to analyze factors influencing adoption of mobile money among university students in Tanzania.

\section{LITERATURE REVIEW}

\subsection{Theoretical Literature Review}

This part aimed at selecting appropriate theory/models that informed the researcher on the variables to be included in the development of a conceptual model in the process of analyzing the critical factors influencing adoption of mobile money services.

\section{Theory of Planned Behavioral}

Ajzen (1991) developed the theory of reasoned action through adding construct perceived behavioral control into the model as a determinant of behavioral intention and 
behavior, and called it as theory of planned behavior. According to Ajzen (1991) the theory of planned behavior state that individual behavioral intention to behave is determined by three factors namely attitude, subjective norms and perceived behavior control. In fact, attitude is the general feeling of people about the desirability or undesirability of a particular issue or behavior. Subjective norm refers to individual's perception of important people's opinions about doing or not doing the behavior. In other words, subjective norm is the perceptions related to opinions of society about doing or not doing the behavior by individual. The construct "perceived control of behavior" is the individual's perception about ease or difficulty of doing behavior and indicates the individual's perceptions about required skills, resources, and opportunities in doing the behavior. The applicability of theory of planned behavioral is evidenced in a number of studies (Makena and Gekara ,2014; Al-fahim, 2012). For example, Makena and Gekara (2014) on their study on behavioral intention to use services of mobile banking system found and concluded that attitude, subjective norm and perceived behavior control are significant influencing behavioral intention to adopt mobile banking. Therefore in this study, this theory helped to inform the researchers and in providing further analysis on the influence of attitude, subjective norm and behavioral control on adoption of mobile money among University students.

\subsection{Empirical Literature Review}

\subsubsection{The Influence of Attitude on Adoption of Mobile Money Services}

Kabir (2013) on mobile banking adoption study,the findings indicate that perceived usefulness, easiness of use, relative advantages and personal innovativeness have significant effect on user"s attitude thus influence the intention toward mobile banking. Aboelmaged and Gebba (2013) on their survey study on mobile banking adoption,the regression results indicated a significant impact of perceived usefulness on attitude toward mobile banking while the effect of perceived easiness of use on attitude toward mobile banking was not supported. On the other hand, Govender and Sihlali (2014) carried out a study on mobile banking adoption among university students. Using multiple regression analysis, the results suggest that trust, perceived value and perceived easiness of use account for intention to use m-banking. The positive attitude of students towards m-banking is a great motivation towards adoption and continuance of using m-banking.

These findings posit a hypothesis (H1) which state that: Attitude has significant influence on mobile money services adoption among university students in Tanzania.

\subsubsection{The Influence of Social Environment on Adoption of Mobile Money Services}

Govender and Sihlali (2014)carried out a study on mobile banking adoption among university students. Using multiple regression analysis, the results indicated that, social influence account for the intention to use m-banking. Kabir (2013) on mobile banking adoption studies, the findings indicate that social norms have significant effect on user intention toward mobile banking. Al-fahim (2012) on his study on the impact of subjective norm on the behavioral intention to use services of banking system, the finding demonstrated that there are significant on students social pressure on intention to use banking services in the context of Yemen.

These findings posit a hypothesis (H2) which state that: Social factor has significant influence on mobile money services adoption among university students in Tanzania.

\subsubsection{The Influence of Facilitating conditions on Adoption of Mobile Money Services}

Makena and Gekara (2014) on their study of factors influencing the use of M-Banking by academics, the results show a positive correlation between customer service and type of bank of m-banking. Kabir (2013) on mobile banking adoption study in Zimbabwe,the findings indicated that perceived risks and costs deterred the adoption of the service. Olasina (2015) on their study of factors influencing students' intention to adopt mobile technology, The findings shows that facilitating conditions such as cost and previous experiences respectively influencing university students to adopt mobile blackboard.

These findings posit hypothesis (H3) which state that: Facilitating condition has significant influence on mobile money services adoption among university students in Tanzania.

\section{Conceptual Frame work}

This frame work composed of three independent variables namely attitude, social influence and facilitating conditions and one dependent variable namely mobile money adoption literature as discussed in the empirical literature in section above and diagrammatically described below. 
Independent Variable

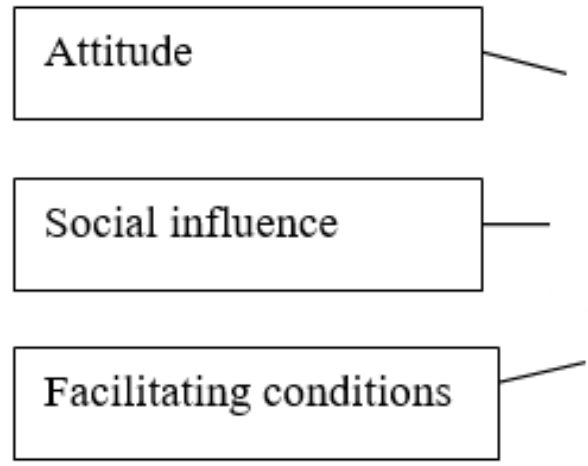

$\mathrm{H} 1$

$\mathrm{H} 2$

$\mathrm{H} 3$

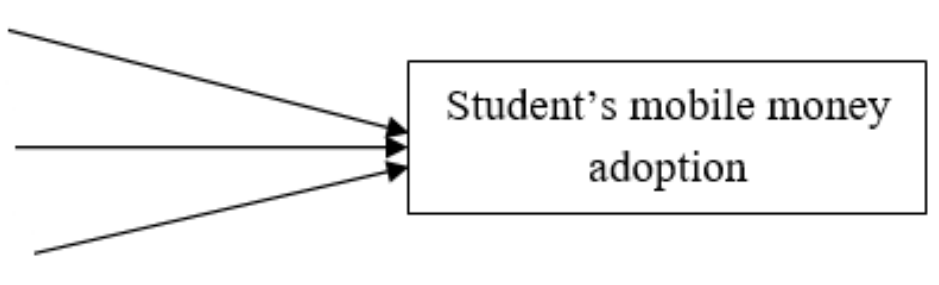

Dependent Variable

Source: developed by authors from literature review (2017)

\section{METHODOLOGY}

Quantitative approach was used in this study. Quantitative philosophy collect data about the study objective and search for causal relationships and knowledge was developed through objective measurement (Saunders, et al., 2012). This study was used quantitative approach in order to determine the magnitude of each factor in influencing adoption of mobile money services among university students. This study was conducted at Ruaha Catholic University. This area is selected because among higher education institutions in Tanzania, Students from RUCU have been using mobile money services for long time. Therefore collecting data from RUCU, helped the researcher to mobilize evidence and get required data in

Table.4.1: KMO and Bartlett's Test

\begin{tabular}{ll}
\hline \multicolumn{2}{l}{ Kaiser-Meyer-Olkin Measure of Sampling Adequacy. } \\
Bartlett's Test of & Approx. Chi-Square \\
Sphericity & Df \\
& Sig.
\end{tabular}

order to understand factors influencing adoption of mobile money services in Tanzanian high learning institutions.Quantitative data analysis was performed by using regression analysis to test the extent or magnitude of each factor influencing students to adopt mobile money services, this wasdone by using multiple regression analysis.

\section{PRESENTATION OF THE FINDING}

\subsection{Construct Validity Test}

Before actual exploratory factor analysis was done KMO and Bartlett's Test was run to ensure sample adequacy and items are correlated enough to carry out factor analysis as it described below in Table 4.2 KMO and Bartlett's Test.
In table 4.1above, the value of KMO of 0.819 was yield which suggested that the sample was adequate for exploratory factor analysis as suggested by Hooper, et al.(2008) who argued that KMO should be either .6 or above. On the other hand Bartletttest in this study yield pvalue $=0.00$ which signify that the variables are correlated highlyenough to provide a reasonable basis for factor analysis as suggested by (ibid) that the value for Bartletttest should be significance value of less than .05 as describe in table 4.1.

After assessing sample and correlation adequacy, exploratory factor analysis with varimax rotation was conducted to assess the underlying structurefor the twenty nine items of the university students' mobile money adoption questionnaire.During analysis out of twenty nine(29) items only seventeen(17) items were retained with four factor based on thefact that the items were designed to index four constructs namely students attitudes, social pressure, facilitating conditions and adoption. These items which did not fit well to the modelwere deleted which includeseasiness of learning,clarity and understandable from Students' attitude construct, Government and Top university management from social pressure construct, agent services, University ICT policy, Government policy, Availability of services provider facilitate from Facilitating conditions and communicate from adoption construct. TheTable 4.2 Rotated Component Matrixa below indicate the items which were not deleted because of their fitness to the model. 
Table.4.2: Rotated Component Matrix ${ }^{a}$

\begin{tabular}{|c|c|c|c|c|}
\hline \multirow[t]{2}{*}{ Items/Dimensions } & \multicolumn{4}{|c|}{ Component } \\
\hline & Attitudes & Social Pressure & $\begin{array}{l}\text { Facilitating } \\
\text { Conditions }\end{array}$ & Adoption \\
\hline $\begin{array}{l}\text { ease to use } \\
\text { speed up transactions } \\
\text { Convenience } \\
\text { fitness of use } \\
24 \text { Hours services } \\
\text { Friends } \\
\text { Lecturers } \\
\text { Vendor } \\
\text { Sponsor } \\
\text { class meet } \\
\text { agents availability } \\
\text { Network Availability } \\
\text { low cost mobile devices } \\
\text { ease to register } \\
\text { availability of vendor facilities } \\
\text { Payment } \\
\text { receive cash } \\
\text { prompt transactions } \\
\text { Access bank services }\end{array}$ & $\begin{array}{l}.885 \\
.853 \\
.791 \\
.790 \\
.775\end{array}$ & $\begin{array}{l}.884 \\
.879 \\
.871 \\
.670 \\
.580\end{array}$ & $\begin{array}{l}.806 \\
.798 \\
.795 \\
.786 \\
.786\end{array}$ & $\begin{array}{l} \\
\\
\\
\\
\\
\\
.876 \\
.872 \\
.863 \\
.547\end{array}$ \\
\hline
\end{tabular}

Extraction Method: Principal Component Analysis.

Rotation Method: Varimax with Kaiser Normalization.

a. Rotation converged in 6 iterations.

\subsection{Reliability Test}

In this study reliability test was done using Cronbach alpha, customarily values above 0.6 of Cronbach alpha coefficients are considered significant (Hair et al.,2006).

Table.4.3: Reliability Test

\begin{tabular}{|l|l|l|l|}
\hline Variables & $\begin{array}{l}\text { No of } \\
\text { Items }\end{array}$ & Items & $\begin{array}{l}\text { Cronbach's } \\
\text { Alpha }\end{array}$ \\
\hline Students attitudes & 5 & $\begin{array}{l}\text { Ease to use, speed up transactions, Convenience, Fitness of } \\
\text { use and 24 Hours services }\end{array}$ & 0.893 \\
\hline Social Pressure & 5 & Friends, vendor ,lecturer, sponsor and class meet & 0.879 \\
\hline Facilitating conditions & 5 & $\begin{array}{l}\text { agents availability, Network Availability, low cost mobile } \\
\text { devices, ease to register and availability of vendor facilities }\end{array}$ & 0.889 \\
\hline $\begin{array}{l}\text { Students Mobile Money } \\
\text { Adoption }\end{array}$ & 4 & $\begin{array}{l}\text { Payment, receive cash, prompt transactions and Access } \\
\text { bank services }\end{array}$ & 0.860 \\
\hline
\end{tabular}

In table 4.3 above, shows that all variables has the p-value of above 6 which means that the items used measures what it is purported to measure and has a good internal consistency of the measures, with items measuring different things for a given factor.

\subsection{Presentation of Major Findings} 4.3.1 The Influence of Students Attitudes on Student Adoption of Mobile Money Services

The significant relationship between students attitudes and adoption of mobile money services was analyzed using multiple regression are presented below on three tables 
able.4.4: Model Summary

\begin{tabular}{|l|r|r|r|r|}
\hline Model & R & \multicolumn{1}{|c|}{ R Square } & Adjusted R Square & Std. Error of the Estimate \\
\hline 1 & $.190^{\mathrm{a}}$ & .036 & .023 & 3.318 \\
\hline
\end{tabular}

a. Predictors: (Constant), speed up transactions, $24 \mathrm{H}$ ours services, fitness of use, Convenience , ease to use

The results provided in table 4.4 above showed that dependent variable "adoption of mobile money" is explained well by independent variable students attitude which has four indicators" speed up transactions, $24 \mathrm{H}$ ours services, fitness of use, Convenience and ease to use" to a small extent as demonstrated by R2 of $36 \%$ which is low percent. Further analysis of the relationship between dependent and independent variable is presented in table 4.5 .

Table.4.5: ANOVA ${ }^{a}$

\begin{tabular}{|rl|r|r|r|r|r|}
\hline Model & & Sum of Squares & Df & Mean Square & F & Sig. \\
\hline \multirow{2}{*}{1} & Regression & 154.935 & 5 & 30.987 & 2.814 & $.016^{\mathrm{b}}$ \\
& Residual & 4151.018 & 377 & 11.011 & & \\
& Total & 4305.953 & 382 & & & \\
\hline
\end{tabular}

a. Dependent Variable: Students Mobile Money Adoption

b. Predictors: (Constant), speed up transactions, $24 \mathrm{H}$ ours services, fitness of use, Convenience, ease to use

The results provided in table 4.5ANOVAa above showed that overall, the model applied in this study statistically significantly predict the outcome variable of relationship between dependent variable" adoption" and independent variable "students attitudes" to a large extent as demonstrated by p-value less than 0.05 in a ANOVA table above. This indicate that the overall hypothesis which state that students attitudes is strongly significant influencing students adoption of mobile money is accepted.These findings do support the attitude variable of the Theory of planned behavior by Ajzen (1991) who argued that attitude is the general feeling of people about the desirability or undesirability of a particular issue or behavior.

Further analysis of the individual indicators on predicting adoption of mobile money services is described in the table below:

Table.4.6: Coefficients ${ }^{a}$

\begin{tabular}{|c|c|c|c|c|c|c|}
\hline \multirow{2}{*}{\multicolumn{2}{|c|}{ Model }} & \multicolumn{2}{|c|}{$\begin{array}{c}\text { Unstandardized } \\
\text { Coefficients }\end{array}$} & \multirow{2}{*}{$\begin{array}{c}\text { Standardized } \\
\text { Coefficients }\end{array}$} & \multirow[t]{2}{*}{$\mathrm{T}$} & \multirow[t]{2}{*}{ Sig. } \\
\hline & & B & Std. Error & & & \\
\hline \multirow{6}{*}{1} & (Constant) & 14.998 & .740 & & 20.272 & .000 \\
\hline & fitness of use & -.008 & .289 & -.002 & -.027 & .979 \\
\hline & $24 \mathrm{H}$ ours services & -.964 & .457 & -.329 & -2.111 & .035 \\
\hline & ease to use & -.036 & .547 & -.011 & -.067 & .947 \\
\hline & Convenience & 1.476 & .483 & .486 & 3.054 & .002 \\
\hline & speed up transactions & -.177 & .455 & -.054 & -.389 & .698 \\
\hline
\end{tabular}

a. Dependent Variable: Students Mobile Money Adoption

The results provided in table 4.6 Coefficients above showed that out of five indicators only two indicator known as fitness of use and convenience were accepted.

\subsubsection{The Influence of Social Pressure on Students Adoption of Mobile Money Services}

This objective was developed to test the hypothesis on the relationship between social pressure and adoption of mobile money services. Finding using multiple regression are presented below on three tables 
Table.4.7: Model Summary

\begin{tabular}{|l|r|r|r|r|}
\hline Model & \multicolumn{1}{|c|}{ R } & \multicolumn{1}{c|}{ R Square } & Adjusted R Square & Std. Error of the Estimate \\
\hline 1 & $.409^{\mathrm{a}}$ & .167 & .156 & 3.084 \\
\hline
\end{tabular}

a. Predictors: (Constant), vendor, class meet, Sponsor, lecturers, Friends

The results provided in table 4.7 above showed that dependent variable "adoption of mobile money" is explained well by independent variable social pressure which has four indicators" vendor, class meet, Sponsor, lecturers and Friends" to a small extent as demonstrated by R2 of $16 \%$ which is low percent. Further analysis of the relationship between dependent and independent variable is presented in table 4.8 .

Table.4.8: ANOVA ${ }^{a}$

\begin{tabular}{|rl|r|r|r|r|r|}
\hline \multicolumn{1}{|l|}{ Model } & Sum of Squares & Df & Mean Square & F & Sig. \\
\hline \multirow{3}{*}{1} & Regression & 720.202 & 5 & 144.040 & 15.144 & $.000^{\mathrm{b}}$ \\
& Residual & 3585.751 & 377 & 9.511 & & \\
\cline { 2 - 5 } & Total & 4305.953 & 382 & & & \\
\hline
\end{tabular}

a. Dependent Variable: Students Mobile Money Adoption

b. Predictors: (Constant), vendor, classmate, Sponsor, lecturers, Friends

The results provided in table 4.8 ANOVA a above showed that overall, the model applied in this study statistically significantly predict the outcome variable of relationship between dependent variable" adoption" and independent variable "students attitudes" to a large extent as demonstrated by p-value less than 0.05 in a ANOVA table above. This indicate that the overall hypothesis which state that social pressure is strongly significant influencing students adoption of mobile money is accepted. This finding is supporting Ajzen (1991) theory of planned behavior who developed subjective norm variable by argued that individual's perception of important people's opinions about doing or not doing the behavior could develop behavior intention to adopt technology. Similar, Taylor and Todd (1995) argued on subjective norm as a perceptions related to opinions of society about doing or not doing the behavior by individual. Further analysis of the individual indicators on predicting adoption of mobile money services is described in the table below:

Table.4.9: Coefficients ${ }^{a}$

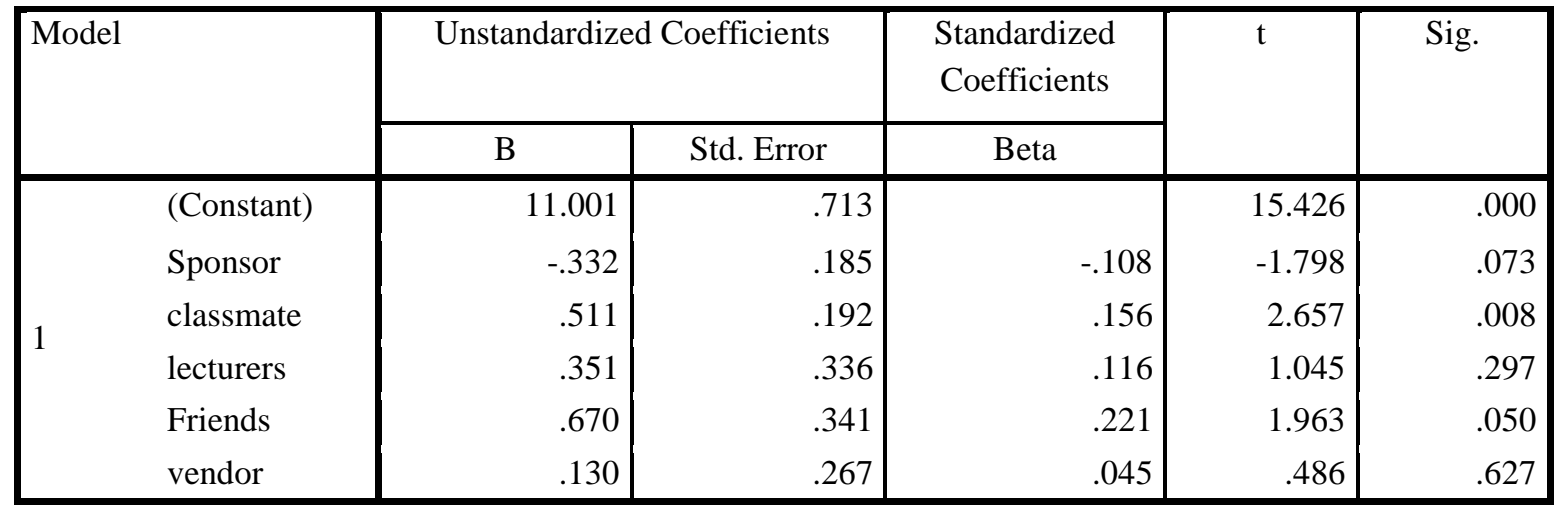

a. Dependent Variable: Students Mobile Money Adoption

The results provided in table 4.9 Coefficients above showed that out of five indicators only one indicator known as classmate were accepted. 
4.3.3 The Influence of Facilitating Condition on

Students Adoption of Mobile Money Services

The Significant relationship between facilitating conditions

and adoption of mobile money services was analyzed by using multiple regression are presented below on three tables

Table.4.10: Model Summary

\begin{tabular}{|l|r|r|r|r|}
\hline Model & \multicolumn{1}{|c|}{$\mathrm{R}$} & R Square & Adjusted R Square & Std. Error of the Estimate \\
\hline 1 & $.381^{\mathrm{a}}$ & .145 & .134 & 3.125 \\
\hline
\end{tabular}

a. Predictors: (Constant), ease to register, low cost mobile devices, Network Availability, availability of vendor facilities, agents availability

The results provided in table 4.10 above showed that dependent variable "adoption of mobile money" is explained well by independent variable facilitating condition which has four indicators" ease to register, low cost mobile devices, Network Availability, availability of vendor facilities and agents availability" to a small extent as demonstrated by R2 of $14 \%$ which is low percent.

Table.4.11: ANOVA ${ }^{a}$

\begin{tabular}{|rl|r|r|r|r|r|}
\hline Model & & Sum of Squares & Df & Mean Square & F & Sig. \\
\hline \multirow{2}{*}{1} & Regression & 625.387 & 5 & 125.077 & 12.812 & $.000^{\mathrm{b}}$ \\
& Residual & 3680.566 & 377 & 9.763 & & \\
& Total & 4305.953 & 382 & & & \\
\hline
\end{tabular}

a. Dependent Variable: Students Mobile Money Adoption

b. Predictors: (Constant), ease to register, low cost mobile devices, Network Availability, availability of vendor facilities, agents availability

The results provided in table 4.11ANOVAa above showed that overall, the model applied in this study statistically significantly predict the outcome variable of relationship between dependent variable" adoption" and independent variable "facilitating condition" to a large extent as demonstrated by p-value less than 0.05 in a ANOVA table above. This indicates that the overall hypothesis which state that facilitating condition is strongly significant influencing students' adoption of mobile money is accepted. This findings is supporting Ajzen (1991) who argued that individual's perception about ease or difficulty of doing behavior and indicates the individual's perceptions about required skills, resources, and opportunities on adopting a particularly technology.

Further analysis of the individual indicators on predicting adoption of mobile money services is described in the table below:

Table.4.12: Coefficients ${ }^{a}$

\begin{tabular}{|c|c|c|c|c|c|c|}
\hline \multirow[t]{2}{*}{ Mod } & & \multicolumn{2}{|c|}{$\begin{array}{c}\text { Unstandardized } \\
\text { Coefficients }\end{array}$} & \multirow{2}{*}{$\begin{array}{c}\begin{array}{c}\text { Standardized } \\
\text { Coefficients }\end{array} \\
\text { Beta }\end{array}$} & \multirow[t]{2}{*}{$\mathrm{t}$} & \multirow[t]{2}{*}{ Sig. } \\
\hline & & B & Std. Error & & & \\
\hline \multirow{6}{*}{1} & (Constant) & 9.715 & .827 & & 11.748 & .000 \\
\hline & low cost mobile devices & .573 & .278 & .166 & 2.064 & .040 \\
\hline & agents availability & .908 & .518 & .241 & 1.754 & .080 \\
\hline & Network Availability & -.056 & .256 & -.016 & -.218 & .827 \\
\hline & availability of vendor facilities & -.016 & .257 & -.005 & -.061 & .952 \\
\hline & ease to register & .162 & .472 & .046 & .342 & .732 \\
\hline
\end{tabular}

a. Dependent Variable: Students Mobile Money Adoption 
The results provided in table 4.12 Coefficients above showed that out of five indicators only one indicator known as low cost mobile devices were accepted.

\section{CONCLUSIONS}

This part focuses on the major conclusions in lieu of the research objectives:

5.1 The influence of attitude on adoption of mobile money services among university students

Through survey data of university students at Ruaha Catholic University, the study confirms that universitystudents' attitude in Tanzania influence students' adoption of mobile money services. While many dimensions were subjected explain the influence of attitude on adoption of mobile money services, base on the findings this study conclude that only two dimensions namely increasing services accessibility in 24 hours and convenience of services accelerate students attitudes toward adoption of mobile money services. On the other hand, this study conclude that attitudes construct which was borrowed from Theory of planned behavior is applicable in studying students' adoption of mobile money services when modified to fit the social context.

5.2 The influence of social environment on adoption of mobile money services among university students

The study examined the relationship between social pressure and university students' adoption of mobile money services. Results indicate that social pressure is significant influencing university students' adoption of mobile money services. Generally there were significant relationship between social pressure and university students' adoption of mobile money services based on the following dimensions namely vendor, classmate, Sponsor, lecturers, Friends , it is observed that classmate and friends has significant influence on social factor while vendor, Sponsor and lecturers has insignificant influence on social factor to influence university students adoptions of mobile money services. This leads to the conclusion that social pressure which is significantly explained by classmate and friends in this study have a significant relationship with students' adoption of mobile money services.

5.3 The Influence of Facilitating Conditions on Adoption of Mobile Money Services

This study examined the relationship between facilitating conditions and students mobile money adoptions using the following dimensions of facilitating conditions namely ease to register, low cost mobile devices, Network Availability, availability of vendor facilities, agents availability. In all the dimensions of facilitating conditions only low cost mobile devices indicate a strong positive relationship with students' mobile money adoptions. It is therefore concluded that the more low cost of mobile devices are, the more likely they are to facilitate students' mobile money adoption.A general conclusion is drawn that facilitating conditions in the view of the current study is a function of students' mobile money adoption in higher learning institutions.

\section{RECOMMENDATIONS}

This part explains recommendations for action:

It was found that, students' attitudes strongly influencing university students adoption of mobile money services in Tanzania. Based on these findings it is recommended that mobile phone vendors and banks they have to design the mobile money services which are increasing the attitude of university students towards adoption of mobile money services by increasing services accessibility in 24 hours and convenience of services to the users who are university students.

Based on the survey data of this study, it was found that social pressure strongly influencing university students' adoption of mobile money services in Tanzania. For speeding up the adoption of mobile money services in higher learning, this study recommend that services provider to attract more peer pressure such as classmate and friends to use mobile money which will in turn help to increase adoption pressure among university students.

In this study facilitating conditions was strongly influencing adoption of mobile money services among university students, it is therefore recommended that the university and mobile money vendor they have to create conducive facilities which include low cost of mobile devices which will enable the adoption of mobile money services among university students in Tanzania.

\section{REFERENCES}

[1] Al-Fahim,N.H.(2013)An Exploratory Study of Factors Affecting the Internet Banking Adoption: A Qualitative Study among Postgraduate Students.Global Journal of Management and Business Research Finance.13( 8), 23-32.

[2] Aboelmaged, M.G. \& Gebba,T.R. (2013).Mobile Banking Adoption: An Examination of Technology Acceptance Model and Theory of Planned Behavior. International Journal of Business Research and Development. 2(1), 35-50.

[3] Ajzen I (1991). The Theory of Planned Behavior. Organizational Behavior and Human Decision Processes. 50(2), 179-211.

[4] Cudjoe,A.G., Anim, P. A.\& Nyanyofio, J. G. N. (2015).Determinants of Mobile Banking Adoption in 
the Ghanaian Banking Industry: A Case of Access

Bank Ghana Limited. Journal of Computer and Communications, 3(1),1-19.

[5] Delafrooz,N., Taleghani,M., Karami,R., \&Moradi,A.(2013).Factors Affecting the Adoption of Internet Banking. International Journal of Business and Behavioral Sciences. 3(2), 82- 100.

[6] Govender ,I.\&Sihlali,W.(2014)A Study of Mobile Banking Adoption among University Students Using an Extended TAM. Mediterranean Journal of Social Sciences.5(7), 451- 459.

[7] Hamza,H.\& Shah ,A.(2014).Gender and Mobile Payment System Adoption among Students of Tertiary Institutions in Nigeria. International Journal of Computer and Information Technology. 3(1),13-20.

[8] Hair, J. F., Black, W. C., Babin, B. J., \& Anderson, R. E. (2006).Multivariate Data Analysis ( $7^{\text {th }}$ ed.). Upper Saddle River, New Jersey: Prentice Hall.

[9] Hooper, D., Coughlan, J. and Mullen, M. R. (2008).Structural Equation Modelling: Guidelines for Determining Model Fit. The Electronic Journal of Business Research Methods. 6(1). 53 - 60

[10] Kazi,A.K.\&Mannan, M.A.(2013).Factors affecting adoption of mobile banking in Pakistan: Empirical Evidence. International Journal of Research in Business and Social Science.2 (3), 54-61.

[11] Kabir, M.R.(2013).Factors Influencing the Usage of Mobile Banking: Incident from a Developing Country. World Review of Business Research. 3(3), 96 - 114.

[12] Kazemi, A.,Nilipour,A.,Kabiry,N.\& Hoseini, M. M. (2013). Factors Affecting Isfahanian Mobile Banking Adoption Based on the Decomposed Theory of Planned Behavior. International Journal of Academic Research in Business and Social Sciences .3(7), 230245.

[13] Liza,F.Y.(2014).Factors Influencing the Adoption of Mobile Banking: Perspective Bangladesh Global Disclosure of Economics and Business.3(3),92 - 112.

[14] Makena, K. J\& Gekara, G.(2014).Factors Influencing Adoption Of Mobile Money Services Among Institutions Of Higher Learning In Kenya.The strategic business \& change journal of management . 2 (20), 381-401.

[15] Olasina ,G.(2015)Factors Influencing The Use Of Mbanking By Academics: Case Study SMS-Based MBanking. The African Journal of Information Systems.7(4),56-76.

[16] Saunders, M., Lewis, P., \& Thornhill, A. (2012).Research methods for business students $\left(6^{\text {th }}\right.$ ed.). England: Harlow Pearson Educational Limited.
[17] Taylor, S., Todd, P. A.(1995). Understanding information technology usage: A Test of competing models. Information Systems Research.6 (2), 145-177.

[18] United Republic of Tanzania (2007).Information and Communication Technology Policy for Basic education.

[19] Yu,C.(2012).Factors Affecting Individuals to Adopt Mobile Banking .Journal of Electronic Commerce Research. 13( 2),104- 121. 